\title{
頭蓋内原発悪性リンパ腫
}

\author{
自験例 9 例の郜床病態と転帰
}

松元 幹郎・大塚 隆嗣·黒木 貴夫 ·柴田 家門·寺尾 栄夫 ·工藤 玄恵*

\section{Primary Intracranial Malignant Lymphoma}

Report of Nine Cases

Mikiro Matsumoto, Takatsugu Ohtsuka, Takao Kuroki, Iekado Shibata,
Hideo Terao and Motoshige Kudo*

Departments of Neurosurgery and ${ }^{*}$ Pathology, Toho University, Tokyo

\begin{abstract}
Nine cases of primary intracranial malignant lymphoma, which accounts for $3.3 \%$ of all intracranial tumors seen in the authors' institution, were studied in terms of diagnostic computed tomographic (CT) features, the tumors' histologic appearance, treatment, post-treatment blood immunologic and cerebrospinal fluid (CSF) characteristics, and outcome. The patients were seven males and two females aged 42 to 67 years. Their chief signs and symptoms on admission were intracranial hypertension, focal signs, and disturbance of consciousness. CT, which proved the most useful preoperative diagnostic technique, demonstrated multiple lesions in seven cases and, in all cases, regions of isodensity or slight high density that were enhanced by contrast medium. According to the patterns of enhancement, the tumors were classed as diffuse (three cases) or nodular (six cases). The former is considered typical of malignant lymphoma, whereas the latter type was sometimes indistinguishable from metastatic tumor and meningioma. At surgery, one patient underwent radical tumor excision, two partial removal, and six biopsy only. Histologic examination revealed one tumor to be of the diffuse small cell type, three of the medium cell type, and five of the large cell type (Lymphoma Study Group classification). Of seven tumors in which lymphocytes were examined by peroxidase-antiperoxidase staining, four were of the B cell type. Postoperatively, whole brain irradiation with 29 to $46 \mathrm{~Gy}$ was followed by local irradiation with 15 to $50 \mathrm{~Gy}$. If the tumor persisted, one of three chemotherapies was administered. In one case, methotrexate was given intrathecally. Seven patients were divided into two groups: long remission (three) and recurrence (four). These two groups were compared in terms of serum immunoglobulin levels, $\mathrm{T}$ and $\mathrm{B}$ cell ratios, CSF characteristics, CT features, tumor cell type, and treatment. No clear differences were found.
\end{abstract}

Key words: malignant lymphoma, computed tomography, radiation therapy

\section{I はじめに}

これまで頭蓋内原発悪性りンパ腫はきわわてまれで, 全

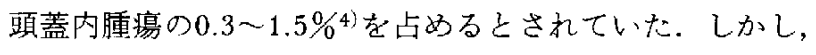
近年, 診断技術の進歩に加兄，免疫抑制剂の使用 ${ }^{17)}$, 放射 楾の影響23)，本た欧米での後天性免度不全症候群(AIDS)

東邦大学脳神経外科 *同病理

Address reprint requests to: M. Matsumoto, M.D., Department of Neurosurgery, Toho University, 6-11-1 Ohmori-nishi, Ohta-ku, Tokyo 143.

受稿 1987年12月25日受理 1988年. 5 月25日 
患者の増加5,18)などにより，発生そのものも明らかに増加 しつつあり，近い将来，脳外科領域に拈ける重要な疾患の 一つになると思われる，頭蓋内原発悪性リンパ腫について は，臨床的にもまだ解明されるべき幾多の問題がある。今 回，我々の経験した症例について，特に病態之転㷌につい て文献的考察を加觉て検討したので報告する．

\section{II 症例と検討方法}

過去 5 年間に我々の施設におい, 組織学的に頭蓋内原発 悪性りンパ腫之診断された 9 症例(全頭蓋内腫瘍の $3.3 \%$ ) の病態と転帰を検討し，ついで特に臨床的再発因子の検索 を行った。店技，全例に批いて全身のRIシンチ，CT， 骨䯣穿刺を行い，全身性悪性リンパ腫の存在を否定した。

\section{III 結 果}

\section{1. 臨床病態}

（1） 性別と年齢 (Table 1)

症例は男性 7 例，女性 2 例で男性に多く，年齢注42才加 ら67才(平均53才)で中・高年集中していた。

\section{(2) 症状}

入院時の症状をみると，頭痛，嘔気，嘔吐などの頭蓋内 压六進症状か５例，片麻痺，失語症，小脳症状，視野障害
などの单症状が 5 例，意識障害が 2 例，失見当識，異常行 動，痤尜発作がそれぞれ1例にみられた。

\section{(3) 診断}

一般に頭蓋内原発覀性りンパ腫は routineな補助検查て は特改的な所見に欠けると言われている，我々も 9 例中 7 例に脳血管撮影を行い，1 例のみに capillary blush を認め たが，他はすべて avascularな mass signのみであった。 CT 汢全例に行われ，9例中 7 例が多発巣で, meningeal spreadは 1 例名認めなかった(Table 1).CT 所見は全例， plain CTでは isodensityかややhigh densityを示し, 造影 妌にて enhancementされた。

我々はさらにその enhancement の性状に上り，症例を diffuse type 3 例 ( $($ 症. 例 1, 2, 7$\rangle$ ) nodular mass type 6 例 (〈应例 3〜6, 8,9〉) 亿分類した(Fig. 1). diffuse type 沬連 瘍の境界がやや不鮮明で，周囲の浮腫も軽く, mass effect の少ないぬので，この type法悪性りンパ腫に比較的特徵 的な所見と考えられた。一方，nodular mass type は境界 が明瞭で, 周囲の浮腫も強く, mass effect む強いもので, 車云移性脳腫瘍，髄膜腫との鑑別が困難であった症例がそれ ぞれ 1 例ずつ(前者は〈症例 3〉，後者は〈症例 4〉方った。 しかし，頭蓋内原発覀性リンパ腫の骖断は CTによりかな りの確率で可能であると考劣られた。

Table 1 Glinical data of nine cases of primary intracranial malignant lymphoma

\begin{tabular}{|c|c|c|c|c|c|c|c|c|c|}
\hline $\begin{array}{l}\text { Case } \\
\text { No. }\end{array}$ & $\begin{array}{l}\text { Age/ } \\
\text { Sex }\end{array}$ & Tumor location & Surgery & Histologic type* & $\begin{array}{l}\text { Cell } \\
\text { type }\end{array}$ & Radiation & $\begin{array}{l}\text { Other } \\
\text { treatment }\end{array}$ & $\begin{array}{l}\text { Recur- } \\
\text { rence }\end{array}$ & Outcome \\
\hline 1 & $56 / \mathrm{M}$ & $\begin{array}{l}\text { corpus callosum, } \\
\text { bil. parietal }\end{array}$ & biopsy & diffuse, large & $\mathrm{T}$ & $\begin{array}{l}\text { whole brain }(30 \mathrm{~Gy}) \\
\text { local }(15 \mathrm{~Gy})\end{array}$ & $\begin{array}{l}\text { MTX (intra- } \\
\text { thecal) }\end{array}$ & - & $\begin{array}{l}\text { alive }(1 \mathrm{yr} \\
10 \mathrm{mos})\end{array}$ \\
\hline 2 & $57 / \mathbf{F}$ & $\begin{array}{l}\text { corpus callosum, } \\
\text { basal ganglia }\end{array}$ & biopsy & diffuse, medium & B & whole brain ( $46 \mathrm{~Gy})$ & $\mathrm{ACNU}$ & - & $\begin{array}{l}\text { alive }(4 \text { yrs } \\
4 \mathrm{mos})\end{array}$ \\
\hline 3 & $44 / \mathrm{M}$ & $\begin{array}{l}\text { lt. frontal, } \\
\text { rt. parietal }\end{array}$ & $\begin{array}{l}\text { partial } \\
\text { removal }\end{array}$ & diffuse, large & B & $\begin{array}{l}\text { whole brain }(30 \mathrm{~Gy}) \\
\text { local }(44 \mathrm{~Gy}, 40 \mathrm{~Gy})\end{array}$ & CHOP & - & $\begin{array}{l}\text { alive }(1 \text { yr } \\
3 \text { mos })\end{array}$ \\
\hline 4 & $42 / \mathrm{M}$ & rt. occipital & $\begin{array}{l}\text { radical } \\
\text { removal }\end{array}$ & diffuse, large & B & $\begin{array}{l}\text { whole brain }(29 \mathrm{~Gy}) \text {, } \\
\text { local }(50 \mathrm{~Gy})\end{array}$ & & $3 \mathrm{mos}$ & died $(7 \mathrm{mos})$ \\
\hline 5 & $57 / \mathrm{M}$ & $\begin{array}{l}\text { rt. basal ganglia, } \\
\text { pineal }\end{array}$ & biopsy & diffuse, medium & - & $\begin{array}{l}\text { whole brain }(30 \mathrm{~Gy}) \text {, } \\
\text { local }(50 \mathrm{~Gy})\end{array}$ & CHOP & $2 \mathrm{mos}$ & $\begin{array}{l}\text { died }(1 \mathrm{yr} \\
6 \mathrm{mos})\end{array}$ \\
\hline 6 & $49 / \mathrm{M}$ & cerebellar & $\begin{array}{l}\text { partial } \\
\text { removal }\end{array}$ & diffuse, medium & - & local $(50 \mathrm{~Gy})$ & $\mathrm{ACNU}, \mathrm{CHOP}$ & $4 \mathrm{mos}$ & $\begin{array}{l}\text { died }(2 \mathrm{yrs} \\
5 \mathrm{mos})\end{array}$ \\
\hline 7 & $67 / \mathrm{M}$ & $\begin{array}{l}\text { rt. basal ganglia, } \\
\text { rt. midbrain, } \\
\text { lt. hypothalamus, } \\
\text { bil, lateral } \\
\quad \text { ventricles }\end{array}$ & biopsy & diffuse, small & $\mathrm{NE}$ & whole brain (41Gy) & & $4 \mathrm{mos}$ & $\begin{array}{l}\text { died }(1 \mathrm{yr} \\
3 \mathrm{mos})\end{array}$ \\
\hline 8 & $50 / \mathrm{M}$ & $\begin{array}{l}\text { corpus callosum, } \\
\text { lt. basal ganglia }\end{array}$ & biopsy & diffuse, large & B & $\begin{array}{l}\text { whole brain }(29 \mathrm{~Gy}) \\
\text { local }(21 \mathrm{~Gy})\end{array}$ & & & $\begin{array}{l}\text { alive }(1 \mathrm{yr} \\
7 \mathrm{mos})\end{array}$ \\
\hline 9 & $57 / F$ & $\begin{array}{l}\text { rt. parietal, } \\
\text { lt. frontal, } \\
\text { lt. occipital }\end{array}$ & biopsy & diffuse, large & - & $\begin{array}{l}\text { whole brain ( } 40 \mathrm{~Gy}) \text {, } \\
\text { local }(31 \mathrm{~Gy})\end{array}$ & VEMP & & alive ( $2 \mathrm{mos}$ ) \\
\hline
\end{tabular}

*According to the Lymphoma Study Group. ${ }^{20)}$ NE indicates not examined; ACNU, 1-(4-amino-2-methyl-5-pyrimidinyl) methyl-3- (2chloroethyl)-3-nitrosourea hydrochloride; MTX, methotrexate; CHOP, combination chemotherapy with adriamycin, vincristine, cyclophosphamide, and prednisolone; VEMP, combination chemotherapy with vincristine, cyclophosphamide, methotrexate, and prednisolone. 


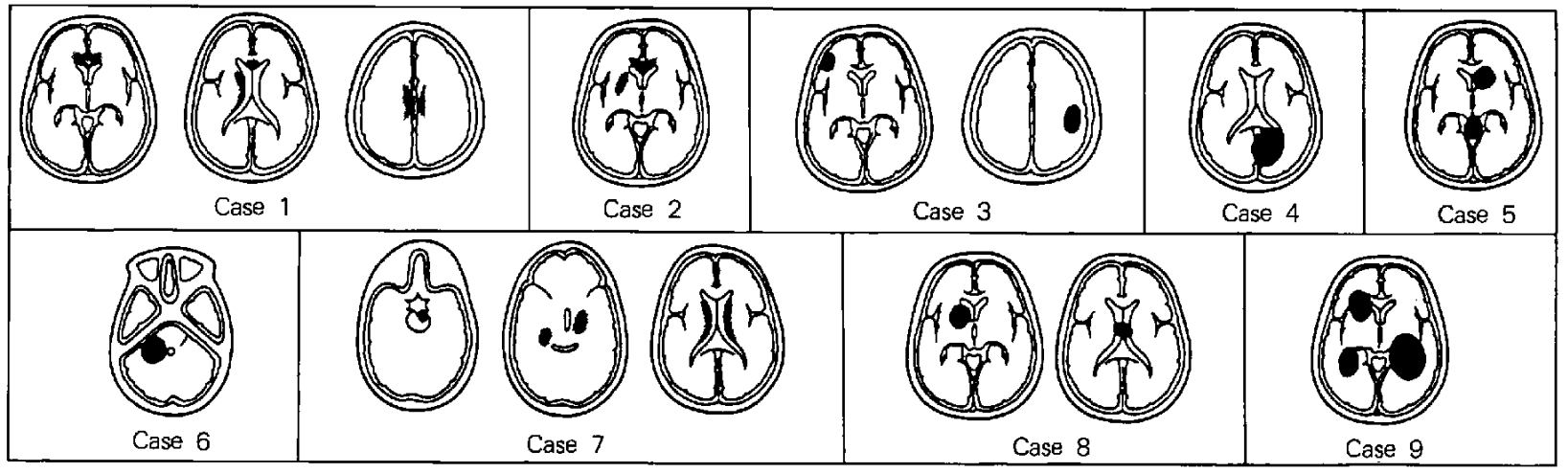

Fig. 1 Tumor locations. The tumors in Cases 1, 2, and 7 were of the diffuse type on contrast-enhanced computed tomography (CT) scan and the others were of the nodular mass type.

Table 2 Laboratory data

\begin{tabular}{|c|c|c|c|c|c|c|c|c|}
\hline \multirow{2}{*}{ Case No. } & \multicolumn{6}{|c|}{ Blood } & \multicolumn{2}{|c|}{ Cerebrospinal fluid } \\
\hline & $\gamma$-globulin $(\%)$ & $\operatorname{IgG}(\mathrm{mg} / \mathrm{d} l)$ & $\operatorname{Ig} \mathrm{A}(\mathrm{mg} / \mathrm{d} l)$ & $\operatorname{IgM}(\mathbf{m g} / \mathrm{d} l)$ & T-cells $(\%)$ & B-cells $(\%)$ & Protein $(\mathrm{mg} / \mathrm{d} l)$ & Cells \\
\hline 1 & 15.8 & 1,389 & 241 & 412 & 88 & $5 \downarrow$ & $88 \uparrow$ & $80 / 3 \uparrow$ \\
\hline 2 & 12.5 & 1,514 & 207 & 358 & 80 & 17 & $132 \uparrow$ & $76 / 3 \uparrow$ \\
\hline 3 & $7.4 \downarrow$ & 1,110 & 168 & 47 & $70 \downarrow$ & $5 \downarrow$ & $121 \uparrow$ & $6 / 3$ \\
\hline 4 & $7.9 \downarrow$ & 956 & $100 \downarrow$ & $31 \downarrow$ & 89 & $7 \downarrow$ & & \\
\hline 5 & $6.3 \downarrow$ & 735 & 116 & $53 \downarrow$ & 82 & 9 & $175 \uparrow$ & $27 / 3 \uparrow$ \\
\hline 6 & 15.4 & 927 & 121 & 34 & 82 & 16 & $98 \uparrow$ & $1 / 3$ \\
\hline 7 & 27.3 & 1,266 & 363 & 180 & 80 & $7 \downarrow$ & $60 \uparrow$ & $8 / 3$ \\
\hline 8 & 14.5 & 1,420 & 140 & 71 & 82 & 9 & $90 \uparrow$ & $27 / 3 \uparrow$ \\
\hline 9 & $8.3 \downarrow$ & $521 \div$ & $99 \downarrow$ & 138 & 81 & $2 \downarrow$ & & \\
\hline
\end{tabular}

IgG indicates immunoglobulin G; IgA, immunoglobulin A; IgM, immunoglobulin M. $\uparrow$ : higher than normal, $\downarrow$ : lower than normal.

\section{（4）検査所見 (Table 2)}

入院時または治療初期に拈ける血㢈検查では，全例で $\gamma$ グロブリン，免疫グロブリン(IgG, IgA, IgM)および $\mathrm{T} \cdot \mathrm{B}$ 細胞を測定し，な 3 例(〈应例 $3,8,9\rangle$ )で $\mathrm{OKT}_{4} /$ $\mathrm{OKT}_{8}$ ratio を，3 例(〈症 例 4,8,9〉) で phytohemagglutinin, concanavalin A E対する blastogenesis $の$ 検索を行っ た. ゲグロブリンは 9 例中 4 例に低值を認め，免疫グロブ リンは 1 例に $\operatorname{IgA} と \operatorname{IgM}$ の低值を，2 例に $\operatorname{IgM} の$ 低值を，

1 例に IgG, IgA の低值を㤎めた。 T・B 細胞の測定では 1 例に $\mathrm{T} \cdot \mathrm{B}$ 両紐胞の，4例にB 細胞の減少を認めた。

$\mathrm{OKT}_{4} / \mathrm{OKT}_{8}$ ratio および blastogenesis した 3 例すべてが $\mathrm{OKT}_{4} / \mathrm{OKT}_{8}$ ratioの低值または逆転と blastogenesis $の$ 低反応を示していた。䯣液検査は 9 例中 7 例に行われたが，全例に蛋白の増加を，4例に細胞の増加 を認めた。な拈，1 例(〈症例 1〉)にて髄液中に腫痬細胞を 証明した。

\section{（5）治療 (Table 1)}

全例に手術が行われたが，全摘出術は噵膜睡と術前診断 された 1 例(〈症例 4〉)のみで，部分摘出術 2 例，biopsy 6 例であり，5ち2例(〈症例 5, 9〉)は Brown-Robert-Wells 装置を用いたCT-guided stereotaxic biopsyであった，我 々は組織診断のつさしだい，まず全例に照射を開始し，原 則として 1 日 2 Gy で30〜 40 Gy を目標に全脳照射を行い， 腫瘍が CT 上消失しない場合，局所に追加照射を行った。 9 例中 8 例(1 例恃局所照射のみ) に29 46 Gy (平均34.4 Gy) 0 全脱照射を行い，9例中 7 例(2 例は全脳照射のみ) に15 50 Gy (平均 $37.3 \mathrm{~Gy}$ ) の局所照射を行った，臨床的 儿资䯣播種と考えられる症例は 1 例孔なく，春髄照射は行 わなかった。このよ5な方法で 9 例中 8 例(88.9\%)に CT 上の腫瘍の完全消失を認めた。化学㞠法は 9 例中 6 例に行 い, ACNU 2 例, CHOP (adriamycin, vincristine, cyclophosphamide, prednisolone) 3 例, VEMP (vincristine, cyclophos- 
phamide, methotrexate, prednisolone) 1例で，そのらち ACNU と CHOP の併用療法が 1 例あり，また髄液中に腫 瘍細胞を認めた 1 例には methotrexateの䯣注を行った。 原則として化学療法は照射終了時より行い，1 4 のみとし，以降の維持療法法行わなかった，再発例には同 様な方法での再照射と化学療法として VEPA (vincristine, cyclophosphamide, prednisolone, adriamycin)(〈症例 4〉), bleomycin (〈症例 5〉), CHOP (〈症例 6, 7〉)妾併用した。

(6) 病理組織学的検索 (Table 1)

HE 染色による病理分類は Lymphoma Study Group 分 類 ${ }^{201}$ によって行い，すべて diffuse typeで, small cell type 1 例, medium cell type 3 例, large cell type 5 例であった。 また，腫瘍組織の醭素抗体法に上る cell typeの倹索を7 例に行い， 1 例に IgA，3 例に IgM $の$ 抗体を証明し，4例 が B-cell type と診断された。髄液中に腫瘍細胞を証明し た 1 例は surface markerの検索で $\mathrm{E}$ rosetteを証明 $し ， \mathrm{~T}$ cell type と考光られた。

\section{2. 転帰之臨床的再発因子の検討}

以上の照射を心とする初期治療により，9例中 8 例に CT 上の腫瘍の消失を認めた。しかし，4例は早期に再発 をみ，現在 9 例中 5 例が生存し，生存期間は初期治療開始 後 2 52 力月（平均 22 力月）であり，死亡例の 4 例はすべて 再発例で, 初期治療後 2 4 4 月 (平均 3.3 力月) で再発し， 初期治療開始後 7〜29 力月 (平均17.3力月) で死亡した。

次に，初期治療て CT 上腫瘍が完全に消失しなかった 〈症例 8〉と初期治療後まだ 2 力しかたっていないく症例 9〉の 2 症例を除いた 7 症例を初期治療後の経過により長期 寛解群 (〈症例 1 3〉) と短期再発群(〈症例 4 7 ) 飞分忛, 臨床的再発因子の有無を検討した。专ず，両群の代表例の 臨床経過を 1 例ずつ提示する。

症例 1：約 3 週間前よりの歩行障害之異常行動のため, 1985年11月 10 日，入院した，入院時，意識清明で，軽度の 失見当識と右不全麻瘒があり，CTで脑梁上両側頭頂葉に diffuse type の enhancement 示寸腫瘍を認めた（Fig. 2A， B). 11 月 20 日，開頭による脳梁部の biopsyを行い, diffuse large cell type $の$ 覀性リンパ腫と診断された。 また， 髄液中に腫瘍細胞が証明された。11月27日より照射を開始 L, 全脳 $30 \mathrm{~Gy}$ に引き続き局所 $15 \mathrm{~Gy}$ 照射 L, CT 上腫 瘍は消失した（Fig. 2C)。蓑た，照射期間中に methotrexate $25 \mathrm{mg}, 30 \mathrm{mg}$ を隔週 2 回で骾注し, 鹃液中の腫瘍細胞は 2 回目の髄注直後に消失した。患者は1986年 1 月 12日，軽 度の右不全麻瘏を残して退院した。しかし，外来通院中， 徐々に失見当識，記銘力障害，ついには失禁を認めるよう になり，同年12月23日，再入院し，精査するも，腫瘍の再 発はなく， CT 上著明な脳萎樎を認めた(Fig. 2D)，患者
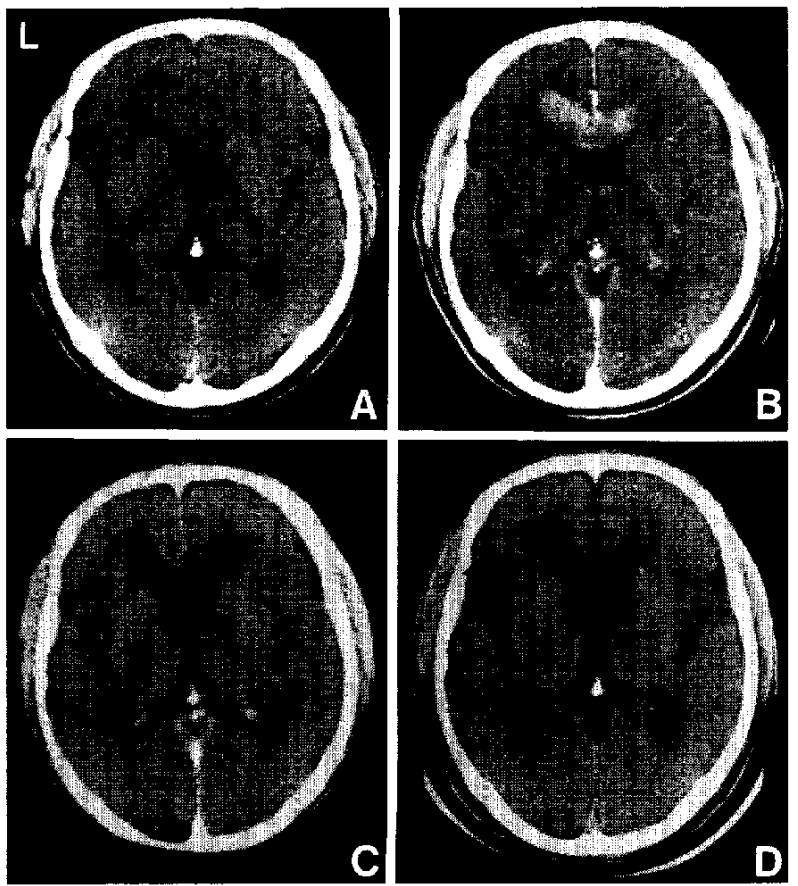

Fig. 2 Case 1. A, B: Plain CT scan (A), showing an isodense tumor and contrast-enhanced CT $\operatorname{scan}$ (B), demonstrating a diffuse type tumor of the corpus callosum. C: CT scan taken at completion of the initial treatment reveals complete disappearance of the tumor. D: CT scan obtained 1 year later shows no evidence of recurrence but indicates cerebral atrophy.

は現在も入院加療中である.

長期寛解群の転㷌に関しての大きな問題は，本症例のよ $5 に 3$ 例とも CT 上脳萎縮が徐々に強くなり，ま大拝状的 にも痴呆状態が強く，現在有為な生活を送っている症例は 1 例もないことである。

症例 4 ：頭痛を主訴として1985年10月30日，精查入院し た，入院時，意識は清明で，左问名性半育の久文認めた。 CTにて右後頭葉に nodular mass type $の$ enhancement 示す腫瘍を認め(Fig. 3A, B)，脳血管写では avascular mass ではあったが，䯣膜腫の診断の下に11月17日，開頭 術にて腫瘍を全摘した。腫瘍は diffuse large cell type の悪 性リンパ腫と診断された。11月25日より全脳 $29 \mathrm{~Gy}$ の照射 を開始し，右後頭葉中心に50 Gy を追加照射し，1986年 2 月20日，左同名性半盲以外に症状を残さず退院した。しか し，同年 5 月 6 日，歩行障害のため再入院し，CT上原発 巣と無関倸な部位の多発性の再発を認めた（Fig. 3C) ため， 再照射拈よびVEPAを開始したが，意識障害も徐々に強 くなり，同年 6 月18日，肺次を併発して死亡した。

この両群の初期治療後の経過の違いが何以よるものか, 

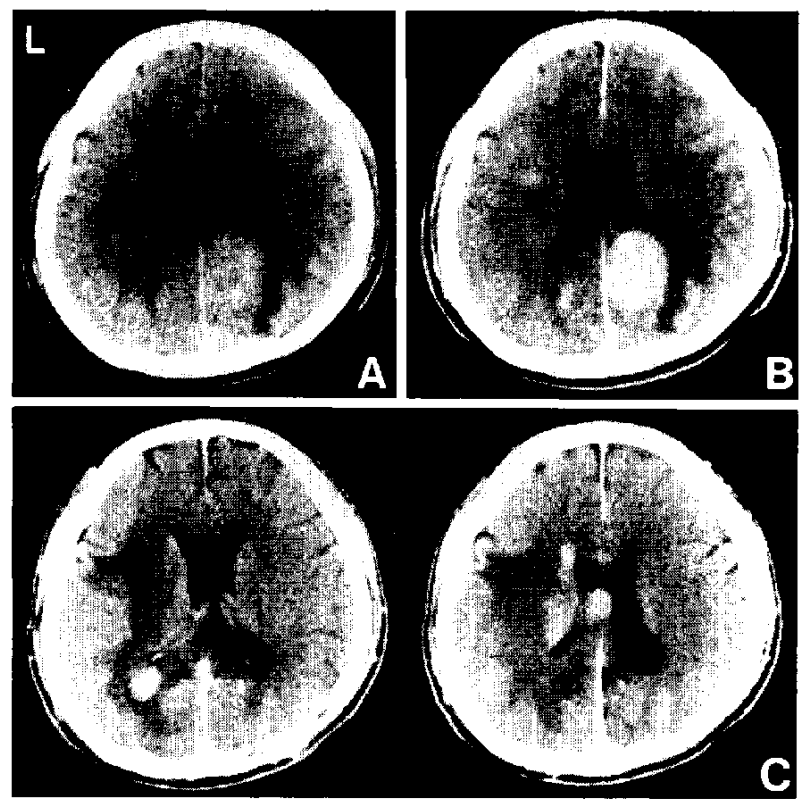

Fig. 3 Case 4. A, B: Plain CT scan (A), showing a tumor of slight high density and contrast-enhanced CT scan (B), revealing a nodular mass type tumor in the right occipital lobe. C: CT scan obtained 3 months after initial treatment, disclosing multiple tumor recurrences.

臨床検査所見などを比較検討した。まず，CT 所見を比較 してみたが，腫瘍の部位，大きさ，末た単発か多発かて両 群間に明らかな差はみら机なかった。杰た, enhancement の性状を々ると，長期寛解群の3 例のらち 2 例が diffuse typeであったが，一方短期再発群の diffuse type の1例は 約 4 力月で再発して括り, diffuse type $と$ nodular mass typeが両群の差として考えらるかは疑問である. 次に両 群の血液所見 $(\boldsymbol{\gamma}$ グロブリン, 免疫グロブリン, $\mathrm{T} \cdot \mathrm{B}$ 細 胞），李た䯣液所見を比較しても明らかな差はみられず， さらに両群の病理分類, cell typeを比較しても差は2られ なかった，次に両群の初期治療を比較してみた，照射量を 比較してみると，長期寛解群の総量は45〜114 Gy (平均 $68.3 \mathrm{~Gy}$ )，短期再発群のそ玌は41 80 Gy（平均62.5 Gy） で，両群に差はなく，宗た化学療法についてし長期宽解群 の 1 例に methotrexateの髄注を行った以外，両群に差は 認められなかった，以上の上らに，長期宽解群，短期再発 群に臨床的事項で明らかな差恃認女られず，初期治療後の 経過を左右寸る因子を明らか心することはできなからた。

\section{$\mathrm{N}$ 考察}

頭蓋内原発覀性りンパ腫の母細胞の起源についてはこれ までに多くの議論がさ机，この腫瘍の名称も intracra- nial sarcoma (1929年, Baily), microgliomatosis（1948年, Russel)，reticulum cell sarcoma（1972年，Rubinstein) と变 遷してきた。しかし，最近の組織学的・免疫学的検索法の 進歩により，その母細胞はりン八細網系由来の芽球化した リンパ球の腫瘍性增殖 ${ }^{14,16,20)}$ と考之られ，ホジキン病以外 の腫湯に対して，主としてアイリカ学派では括して“頭 蓋内原発悪性りンバ腫” (primary malignant lymphoma of the central nervous system) 24) と呼ばれるようになった。さ らに, 酵素抗体法に上り腫瘍細胞内免疫グロブリンの存在 が多くの症例で確認され，多くは $\mathrm{B}$ 細胞系りンパ球由来 上考えられている10,22!

本腫瘍と免疫異常之の関係を指摘する報告は多い，臟器 移植に伴亏減免疫療法 ${ }^{17}$ や化学療法, 放射線療法 ${ }^{23}$ などに 上り人為的に兔疫能の低下した患者, AIDS 患者 ${ }^{5,18)}$ ， た先天性免疫異常患者》での発生が報告されている。一 方，本腫瘍が自然に ${ }^{19)}$ ，息たはステロイドの投与のみで消 失・縮小寸るとの報告1,9) もあり，他の腫瘍にはみられな い特異な生物学的特性を有しており，その発生，また発育 に免疫能かなんらかの関与をしていることは間違いないよ らである、特にその発生については，脳は免疫能の反応の 低い蔵器であるために，上り脳に発生するりンバ腫が多い との報告 ${ }^{17)}$ ，また Epstein-Barr ウイルスの感染を示唆与 る報告6)吉り，興味深い。本報告例では臨床的に免疫異 常を示した症例は 1 例もなかったが， $\mathrm{T}$ 細胞系を検索した 3 症例上も $\mathrm{T}_{4}$ 細胞の减少を認め, 免疫能の低下が示腹さ れた。しかし，これまでの報告例の多くは免疫異常を認め ない症例であり，病因的な差があるのか，今後の問題であ る.

診断に関して, 初発時の臨床症状は頭蓋内压六進, 巣症 状が主なもの 14 亿゙，意識障害と高度の精神症状が特徵的 だとの報告もある(15)が，一般的には他の悪性脸腫瘍と同じ く, 腫暢の部位, 大きさ, 浮腫の程度に起因与ると思われ る。また，特異な症状として uveitisが初発症状であった 症例 ${ }^{8)}$, 難治性 uveitis 合併する症例 ${ }^{13)}$ の報告があり, 注 意を要する.

補助診断手段については，脳血管撮影ではまれに capillary blushをみる症例があるが，多くは avascular mass sign のみを示し ${ }^{1,2,4,10\rangle}$ ，特徴的な所見に欠㚈るのに対 して，現時点ではCTがもっとも有用な補助㟝断法である といらここで諸家の報告も注注一致して括り ${ }^{3 \dagger}$ ，我々の経 験でも多くはCTにて診断可能であった。すなわち，これ までの報告ではCT 所見の特改3,19) は周囲に種々の程度の 浮腫孝伴い, plain CT では isodensity かややhigh density を示し，造影剂で強くenhanceされるとされ，前者は腫瘍 が細胞質が少なく，核の明膫な細胞が密集しているため， 
後者は血管成分に富み，血管周囲への腫瘍細胞の浸潤で血 液脳関門が破填されているためと考えられている191。 た，本腫湯は20 40\%が多発性で10,21)，脳内のどこにも発 生し，前頭葉，頭頂葉，側頭葉を主とする大脳皮質，皮質 下，基底核，視床，脳梁などでの報告があるが，CT 以降 は好発部位として傍脳室 (paraventricle) の報告が多い2,19). 本報告例でも〈症例 3,6 を除く 7 例が側脳室に接した部位 に存在した，CT上鑑別すべきものは髓膜腫，転移性脳腫 瘍, 悪性グリオーマとされている(1,21)が，多発性であるこ と, ring enhancement が少ないこと的，また血管撮影で多 くは avascular massであることより，これらとの鑑別は比 較的容易である。しかし，本報告例の〈应例 3〉の上らに大 脳皮筫，皮筫下に多発する nodular mass type の場合には， 転移性脳腫瘍との鑑別は困難であろう。

本腫瘍に対する治療としては，他の悪性脳腫瘍と同じ く, 手術療法, 放射線尞法, 化学療法が現在主に行初孔て いるが，主体は放射線潦法である。照射によりCT上腫瘍 が消失または縮小したとの報告は多く，また剖検脳で照射 野には腫瘍細胞を認めなかったとの報告 ${ }^{11,12)}$ 女市り，放射 線感受性がきわめて高いことが本腫瘍の特徵と考えられて いる2,4,7). 本報告例でも全摘した 1 例を除く 8 例中 7 例で は照射により腫瘍は完全に消失し，残り1例でも著明に縮 小した，しか子，〈症例 9〉のように比較的大きな腫痬でも 約40 Gy 照射の時点て完全に消失したが，このことは他の 脳腫瘍と異なり，きわめて印象的であった。照射方法につ いては，光䫓レベルでは腫瘍細胞はCT上の腫瘍の外に脳 室上衣下の血管周囲に沿って濔漫性に浸潤していると言わ れ1,11， また多くの再発巣が原発巣と無関係な部位である 場合が多い(1)との理由により，全脳照射が必須であるこ之 も多くの報告者で意見が一致している1,4,12,21)。また，照射 量については現在，30〜50 Gyが一般行われているが， 最低 $50 \mathrm{~Gy}$ の照射は必要だと考光られている

一方，化学寮法も放射線燎法との合併療法として広く行 われ，種々の薬剤が用いられているが，一般に全身性悪性 リンパ腫に比較してその効果を疑問視寸る報告は多い,4,7). 本報告例でる再発例涌常の化学療法を行ったが，CT 上，交大臨床症状上り明らかな効果を認めた症例は1例る なかった。しかし, 最近, methotrexate の大量動脈内また は静脈内投与あるいは䯙腔内投与が行われ，有效であった との報告がある 5 ,7). 本報告例でも易夜中に腫瘍細胞を認 めた長期寞解群の 1 例に methotrexate の䯣腔内投与を行 い, 腫痬細胞の消失を認めたが， methotrexate が脳実質 髄液内入移行すること方，なた多くの症例で腫瘍が脳室腔 に接して存在していることを考光ると，䯠腔内投与を含め た methotrexateの投与は本腫煬に対する有効な化学療法
の一つとなりらるかもしれないまた，ステロイドのみで 臨床症状の改善之CT上の腫瘍の消失を認めたとの報告む 散見され ${ }^{1,9)}$, ステロイドの抗腫湯作用のみでなく，免疫 能を介して腫瘍細胞の免疫学的活性に影響を与えている可 能性も指摘されており ${ }^{9)}$ ，興味あるが，治㞠法としてのそ の効果はまだ一定でないようである。本た，本腫痬がウイ ルス感染によるとの見地より抗ウイルス戍の投与試みら れているかか，治療効果はまだ不明である。

以上の上5に，本腫場の治㞠は種々行われているが，ま だ有効な治療法は確立されていない，すなわち，現在行わ れている治療法のいかんを問わず，多くの症例て腫瘍は一 時的には消失もしくは縮小寸るが，大部分は再発を繰り返 し，その転㷌はきわめて悪く，平均生存期間は10１5 月2)，5年生存率は $4 \%^{7)}$ とも言和れている。本報告例の 死亡例む再発を繰り返し，平均17.3s月で死亡している。 しかし，なかには15年以上の長期生存例の報告るもあり， 本腫瘍も他の悪性腫瘍と同じように症例により治療に対す る反応性に差がありこれは組織型によるとの報告2も西 るが，本報告例ではこれが何に起因するかは明らかにでき なかった。

以上のことより，今後の治寮法上して，本腫瘍は照射を 中心とする初期治療で多くは一時的な莧解が得られるため に，有効な化学療法剂に上る維持療法の確立が望をれる10)。 我々は，本報告例の長期寛解群にみられた脳萎縮が照射㞠

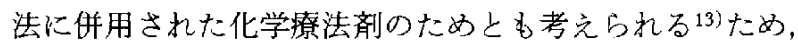
今後の症例に対して，次の方法での治療を試みたいと考兄 ている，すなわち，CTにて本腫場が疑われた場合，開頭 による腫瘍摘出に先立ち，まず stereotaxic biopsyを行い， 組織診断がつきしだい，40〜50 Gy 老日標に，乙かも1回 の照射量を $1.8 \mathrm{~Gy}$ 程度として全脳照射を行い，CT上腫瘍 の消失・縮小が得られたら， methotrexateの䯣注を中心と 寸る化学療法を維持療法とする方法であり，症例を重㸚る ことにより，その有効性を検討したいと考えている。

\section{$\mathrm{V}$ 結 語}

過去 5 年間に我々が経験した頭蓋内原発悪性リンパ腫 9 例について臨床病態と転帰を検討した。

1. 初期治療に上り 9 例中 8 例 $(88.9 \%)$ KT 上の腫瘍 の消失を認めた。

2. 初期治療にて筧解した症例汢以降の経過により長期 寛解群と短期再発群に分けられたが，両者の臨床事項に差 は認められなかった。生た，長期寞解群名全例，失見当 識, 記銘力障害が強く, 有為な生活を送っている症例は 1 例もなかった。

3. 今後, 初期治療に㧍ける照射方法扰よび維持療法に 
おける化学療法の再検討の必要性を痛感した。

本論文の要旨は，第46回日本脳神経外科学会総会(1987年10月， 東京)に打いて発表した。

\section{文献}

1）安芸都司雄, 中村恒夫, 市来崎梁, 岩田隆信, 戸谷重雄, 中野盛夫：Prednisolone が著効を呈した脳原発悪性リンパ腫の 1 例. 脳と神 34: 965-971, 1982

2）安藤彰，斎藤和子，鉿木重晴，岩淵 隆：原発性頭蓋内 悪性リンパ腫の 2 例。脳神外科 12: 191-196, 1984

3）東 和義，野崎公敏，村井知也，児玉安紀，桐本孝次：脳 原発覀性リン八腫の CT 像 - 3 症例報告一. 臨放線 27: 375378, 1982

4) Frank G, Ferrachini R, Spagnolli F, Frank F, Gaist G, Lorenzili P, Ricci R: Primary intracranial lymphomas. Surg Neurol 23: 3-8, 1985

5) Hochberg FH: Primary central nervous system lymphoma. $J$ Neurosurg (in press)

6) Hochberg FH, Miller G, Schooicy RT, Hirsch MS, Feorino P, Henle W: Central nervous system lymphoma related to EpsteinBarr virus. $N$ Engl J Med 309: 745-748, 1983

7) Jones GR, Mason WH, Fishman LS, Declerck YA: Primary central nervous system lymphoma without intracranial mass. Cancer 56: 2806-2808, 1985

8) 神園純一，松橋正和，気賀沢一輝，小沢博子，三方淳男， 秋山健一：後部ら゙どう瞙炎老初発症状とする眼・中枢神経系 原発悪性リンバ腫の 4 例. 眼臨 40: 455-460, 1986

9）北川泰久，後藤文男，厚東第生，森田陽子，石川寿晴，松 山春郎：脳原発性悪性リンバ腫の 1 剖㛟例 一ステロイドの臨 休効果比ついて一，神経内科 18: 386-389, 1983

10）小林達也, 橴谷直樹, 吉田 純, 影山直樹, 曰井和夫, 原 誠, 広田敏行, 須知泰山：頭蓋内原発要性リンパ腫 一その臨 本上病理 - 免疫学的娭討一。朕神外科 11: 917-924, 1983

11）児玉安紀, 藤岡敬己, 向田一敏, 横山 登, 羽田良洋, 楠 本五郎：原発性脳腫瘍に対するりニヤック照射治潦効果の桙 討. 医療 37: 42-47, 1983

12）前田達浩，横田 七，小柏元英，竹内一夫，内 $九$ 崎新也, 赤井契一郎：脳原発性悪性りンバ腫の 1 例 一とくに放射線療
法に対する反省一。臨放線 29: 107-110,1984

13）永谷雅昭，池田宏也，山本和己，日山英子，生塩之敬：経 過中に uveitis を伴った脳原発細網肉腫の1 例. 脳神外科 10: $753-759,1982$

14) 中西功夫, 河野宽一, 久保田紀彦, 土屋良武, 北村徳治, 増田信二, 森泉哲次 : 脳原発性覀性りンパ腫一全身性りンパ 肉腫との比較検討一。脳神外科 10: 35-42, 1982

15）西浦 膂, 武内重二, 半田 肇, 姜 三錫 : 頭蓋内悪性リ ンバ腫。腷神外科 8: 839-844, 1980

16) Rappaport $\mathrm{H}$ : Tumors of the hematopoictic system, in: Atlas of Tumor Pathology, section III, fascicle 8. Washington DC, Armed Forces Institute of Pathology, 1966, pp 1-442

17) Schench SA, Penn I: De-novo brain tumors in renal transplant recipients. Lancet 1: 983-986, 1971

18) Snider WD, Simpson DM, Aronyk KE, Nielsen SL: Primary lymphoma of the nervous system associated with AIDS. $N$ Engl J Med 308: 45, 1983

19）園田 寛, 松角康彦，賀来素之：頭蓋内原発覀性リンパ腫 の生物学的特異性一興味ある3症例について一. Neurol Med Chir (Tokyo) 23: 483-489, 1983

20）須知泰山，若狭治毅，三方淳男，難波紜二，菊地昌弘，森 茂郎, 毛利昇, 渡辺昌, 社本幹博, 田島和雄, 張 $九$ 谷健 一，桐野有爾，高木敬三，福永真治，板垣哲郎，松田幹夫： 非ホジキンリンパ腫一病理組織䛦断の問題点一新分類の提 案一一. 最新医 34: 2049-2062, 1979

21）高橋立夫，中村鋼二，佐々木康夫：䯣膜播種で発症した小 巟頭蓋内原発悪性yンパ腫の1例。脳神外科 13: 327-334, 1985

22) Taylor CR, Russel R, Lukes RJ, Davis RL: An immunohistological study of immunoglobulin content of primary central nervous system lymphomas. Cancer 41: 2197-2205, 1978

23) Zimmerman HM: Malignant lymphomas of the nervous system. Acta Neuropathol [Suppl] (Berl) 6: 69-74, 1975

24) Zülch $\mathrm{KJ}$ : Histological typing of tumors of the central nervous system, in: International Histological Classification of Tumors, vol 21. Genova, WHO, 1978, pp 56-57

[別刷請求先： $\boldsymbol{\top} 143$ 東京都大田区大森西6-11-1, 東邦大学脳神 経外科，松元幹郎了 